ARGIPA. 2018. Vol. 3, No. 2: 67-79

Available online: $h$ ttps://journal.uhamka.ac.id/index.php/argipa

p-ISSN 2502-2938; e-ISSN 2579-888X

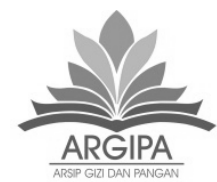

\title{
PENGGUNAAN TEPUNG DAUN KELOR PADA PEMBUATAN CRACKERS SUMBER KALSIUM
}

\author{
Aplication of flour Moringa oleifera leaves in the making of calcium source crackers
}

\author{
Yustika Fahreina Laila Mazidah'1)*, Indah Kusumaningrum²), dan Debby Endayani \\ Safitri2) \\ 1)Nutritionist, KALCare, PT Kalbe Nutritionals; 2)Prodi Gizi, Fakultas Ilmu-ilmu Kesehatan, Universitas \\ Muhammadiyah Prof. DR. Hamka \\ *Email korespondensi: yustika.reina@gmail.com
}

\begin{abstract}
ABSTRAK
Moringa oleifera (kelor) merupakan salah satu sayuran hijau yang kaya akan zat gizi dan mulai dikembangkan dalam produk pangan olahan. Tujuan penelitian ini adalah untuk memanfaatkan daun kelor untuk dijadikan crackers sebagai selingan yang disukai remaja dan dapat memenuhi kebutuhan gizi remaja. Penelitian ini menggunakan rancangan acak lengkap dengan 2 kali pengulangan. Substitusi tepung daun kelor terhadap tepung terigu pada pembuatan crackers yaitu, F0 (100:0), F1 (90:10), F2 (85:15), dan F3(80:20). Penentuan crackers daun kelor terbaik menggunakan uji hedonik dengan panelis semi terlatih. Analisis data menggunakan uji Kruskall Wallis, dengan uji lanjut Mann Whitney. Semakin tinggi tingkat substitusi tepung daun kelor terhadap tepung terigu, tingkat kesukaan panelis terhadap warna, tekstur, rasa, dan aroma crackers semakin menurun. Produk crackers terpilih adalah F1, dengan warna hijau kecoklatan, tekstur renyah, rasa tidak pahit, dan aroma biasa. Produk crackers terpilih dalam $100 \mathrm{~g}$ mengandung energi 456,1 kkal, karbohidrat 67,1 g, protein 8,9 g, lemak 16,9 g, zat besi 3,05 mg, dan kalsium $324 \mathrm{mg}$. Crackers daun kelor terpilih dapat diklaim sebagai makanan sumber kalsium.
\end{abstract}

Kata kunci: Moringa oleifera, Tepung Daun Kelor, Crackers Daun Kelor, Kalsium

\section{ABSTRACT}

Moringa oleifera is one of the green vegetables rich in nutrients and began to be developed in processed food products. The purpose of this study was utilize Moringa oleifera leaves as processed foods that can be consumed as snack by teenagers, helping to fulfill their nutritional needs. This study used a randomized experimental design one factorial with two repetitions. The substitution level of Moringa Leaf flour in the making of crackers were F0 (100:0), F1 (90:10), F2 (85:15), and F3(80:20). The best Moringa leaf crackers was determined by hedonic test with semi-trained panelists. Analysis of data used Kruskall Wallis test, followed by Mann Whitney test. It was known that the higher level of Moringa leaves flour substitution the lower level of panelists's acceptance (color, texture, flavor, and aroma). The selected product was F1, had a brownish-green color, crispy texture, unbitter taste, and normal aroma. This cracker, per $100 \mathrm{~g}$, contained energy $456.1 \mathrm{kcal}, 67.1 \mathrm{~g}$ of carbohydrates, $8.9 \mathrm{~g}$ proteins, $16.9 \mathrm{~g}$ fats, $3.05 \mathrm{mg}$ irons, and $324 \mathrm{mg}$ calcium. The selected crackers can be claimed as snack of calcium source.

Keywords: Moringa oleifera, Moringa Leaf Flour, Moringa Leaves Crackers, Calcium 


\section{PENDAHULUAN}

Fase remaja merupakan peralihan dari masa kanak-kanak menuju masa remaja, ditandai dengan terjadinya perubahan seperti pertambahan massa otot, bertambahnya jaringan lemak, dan juga terjadi perubahan hormonal dalam tubuh. Perubahan-perubahan yang terjadi serta tingginya aktivitas fisik menyebabkan kebutuhan energi, protein, dan mikronutrien pada usia remaja cenderung meningkat dan perlu diutamakan (Adriani dan Wirjatmadi, 2012).

Body image merupakan gambaran persepsi seseorang tentang tubuh ideal dan harapan terhadap bentuk tubuhnya yang didasarkan pada persepsi orang lain (Denich dan Ifdil, 2015). Ketidakpuasan akan body image membuat remaja putri melakukan upaya-upaya diet seperti hanya makan sekali sehari, ataupun mengurangi konsumsi pangan hewani sehingga memengaruhi kecukupan makronutrien dan mikronutrien pada remaja, di antaranya zat besi dan kalsium.

Menurut Balitbangkes (2013) prevalensi kejadian anemia defisiensi besi pada remaja putri 13-18 tahun adalah $22,7 \%$. Studi yang dilakukan terhadap beberapa remaja putri di wilayah DKI Jakarta menunjukkan prevalensi anemia sebesar 36,5\% yang sebagian besar disebabkan oleh kurangnya asupan zat besi dari makanan yang dikonsumsi (Sondari, 2013). Zat besi merupakan mineral mikro yang berperan penting dalam pembentukan hemoglobin. Selain untuk pembentukan hemoglobin pada remaja, meningkatkan fungsi kognitif pada otak, meningkatkan produktivitas kerja, meningkatkan kekebalan tubuh, pada remaja putri zat besi dibutuhkan untuk mengganti zat besi yang hilang akibat menstruasi. Tidak tercukupinya asupan zat besi dapat menyebabkan tubuh mengalami anemia sehingga berdampak pada prestasi menurun, penurunan produktivitas kerja, dan penurunan antibodi tubuh sehingga mudah terserang infeksi (Almatsier, 2010). Selain itu, remaja anemia dapat berisiko melahirkan bayi BBLR dan meningkatkan risiko kematian pada ibu (Scholl \& Hedigier., 1994). Kebutuhan zat besi yang dianjurkan untuk remaja per hari adalah $26 \mathrm{mg}$ per kg BB.

Studi yang dilakukan di kota Bandung diketahui sebanyak 76,2\% remaja memiliki asupan kalsium di bawah AKG dengan rata-rata asupan kalsium per hari adalah 559,05 mg per hari (Fikawati, et al., 2005). Studi yang dilakukan pada remaja putri di Kota Semarang, dilaporkan bahwa sebanyak $70,8 \%$ remaja memiliki asupan kalsium di bawah AKG dengan rata-rata asupan kalsium per hari adalah 622,74 mg/hari (Rahmawati, 2012). Memasuki usia remaja, kebutuhan kalsium meningkat dibandingkan dengan usia anak dan usia dewasa. 
Hal ini disebabkan pada masa ini terjadi peningkatan perkembangan otot, kerangka tubuh, dan kelenjar endokrin. Pada puncak pertumbuhan cepat, penyimpanan kalsium harian dapat mencapai dua kali lipat dari rata-rata penyimpanan selama periode remaja usia 10 hingga 20 tahun (Almatsier, 2010; Adriani dan Wirjatmadi, 2012).

Kebutuhan kalsium yang dianjurkan untuk remaja per hari adalah 1200 mg. Remaja merupakan kelompok masyarakat yang berisiko defisiensi kalsium (Beto, 2015). Defisiensi kalsium dapat mengganggu proses diferensiasi proliferasi sel tulang (Beto, 2015).

Kelor atau Moringa oleifera merupakan salah satu sayuran hijau yang kaya akan zat gizi. Setiap bagian tanaman kelor dapat dimanfaatkan, salah satunya daun kelor. Beberapa penelitian telah melaporkan bahwa daun kelor mengandung kalsium setara dengan 4 kali kalsium pada susu dan zat besi setara dengan 3 kali zat besi pada bayam (Bey, 2010). Dalam 100 gram daun kelor kering, mengandung zat besi 25,7 $\mathrm{mg}$ dan kalsium $4310 \mathrm{mg}$ (Osuagwu, et al., 2014).

Crackers merupakan salah satu jenis biskuit yang digemari masyarakat dan populer di kalangan remaja putri karena penggunaannya lebih luas sebagai makanan diet. Sebanyak 19,6\% masyarakat DKI Jakarta yang berusia $\geq 10$ tahun mengonsumsi biskuit dan angka ini berada di atas rerata nasional (Balitbangkes, 2013).

Crackers termasuk ke dalam biskuit dengan jenis adonan hard dough yaitu jenis adonan yang memiliki kandungan lemak dan gula yang rendah serta memiliki kandungan air yang lebih banyak dari lemak (Manley, 2000). Pada proses pembuatannya, crackers memerlukan proses fermentasi, serta melalui proses laminasi sehingga menghasilkan bentuk pipih dan bila dipatahkan penampangnya tampak berlapis-lapis (Kementrian Perindustrian, 2015).

Menurut Manley (2000), bahan yang digunakan dalam pembuatan crackers dikategorikan menjadi dua yaitu bahan-bahan yang berfungsi sebagai pengikat dan bahan pelembut tekstur. Bahan pengikat atau pembentuk adonan yang kuat adalah tepung terigu, air, dan garam, sedangkan bahan-bahan yang berfungsi sebagai pelembut tekstur adalah gula, mentega, dan leavening agent (baking powder) sebagai bahan pengembang. Pada penelitian ini digunakan bahan tambahan lain yaitu susu bubuk untuk meningkatkan rasa dan aroma crackers serta tepung beras untuk meningkatkan tekstur crackers.

Daun kelor yang telah dikeringkan, digiling menjadi tepung daun kelor. Penggunaan tepung daun kelor pada pembuatan crackers digunakan sebagai pensubstitusi tepung terigu yang umum digunakan sebagai bahan pembuat crackers. Tepung terigu merupakan bahan 
dasar pembuatan crackers dan merupakan komponen yang paling banyak. Tepung berfungsi sebagai pembentuk adonan selama masa pencampuran, menarik atau mengikat bahan lainnya, serta mendistribusikan secara merata, mengikat gas selama proses fermentasi, selama pemanggangan dan membentuk struktur biskuit serta memegang peranan penting dalam pembentukan citarasa (Matz dan Matz dalam Friska, 2002).

Untuk mengurangi penggunaan tepung terigu maka dilakukan substitusi tepung terigu dengan tepung daun kelor (Moringa oleifera). Oleh karena itu, dalam rangka meningkatkan pemanfaatan sumber daya lokal yang ada serta meningkatkan nilai gizi crackers, dilakukan substitusi tepung daun kelor pada pembuatan crackers sehingga crackers yang dihasilkan dapat diklaim sebagai crackers sumber zat besi dan kalsium.

\section{METODE}

Penelitian ini dilaksanakan pada bulan Maret hingga Agustus 2017. Pembuatan tepung daun kelor dan crackers dengan substitusi tepung daun kelor dilakukan di Balai Pasca Panen Bogor. Analisis proksimat, zat besi, dan kalsium dilakukan di Laboratorium Balai Besar Industri Agro, Bogor. Uji organoleptik dilakukan di Universitas Muhammadiyah Prof. DR. HAMKA. Panelis yang digunakan merupakan panelis semi terlatih dengan jumlah 33 orang.
Bahan-bahan yang digunakan dalam penelitian ini adalah tepung daun kelor (daun kelor diperoleh dari daerah Tigaraksa, Tangerang dan proses pembuatan tepung dilakukan di Balai Pasca Panen Bogor), tepung terigu, minyak nabati, garam, backing powder, ragi, susu bubuk, gula halus, keju, tepung maizena, dan air. Bahan yang digunakan untuk analisis crackers kelor adalah asam sulfat, $\mathrm{H}_{2} \mathrm{SO}_{4}$ pekat bebas nitrogen, larutan katalis tembaga, $\mathrm{CuSO}_{4} .5 \mathrm{H}_{2} \mathrm{O}$ bebas nitrogen, $\mathrm{K}_{2} \mathrm{SO}_{4}$, indikator methyl red (MR)/ bromocresol green (BCG), $\mathrm{HNO}_{3}$, HCL, akuades, batu didih, eter minyak tanah, lanthanium oksida, $\mathrm{La}_{2} \mathrm{O}_{3}$, selen, $\mathrm{CaSPO}_{4}$, dan air.

Alat yang digunakan pada pembuatan tepung daun kelor dan crackers kelor adalah timbangan digital, rolling pin, sendok, oven, cetakan crackers, timbangan digital, wadah untuk bahan, loyang untuk adonan, ayakan, blender, nampan, mixer. Alat yang digunakan untuk analisis adalah oven, neraca analitik, desikator, botol timbang aluminium dengan penutup, labu kjedahl, alat destilasi kjedahl, alat penyuling, labu ukur, gelas beaker, buret, kaca arloji, kertas saring pembungkus (huls), Kertas Whattman, alat peniup, Soxhlet, dan tanur.

\section{Penelitian Pendahuluan}

Tahap penelitian pendahuluan meliputi pembuatan tepung daun kelor, analisis sifat fisik, yaitu rendemen tepung daun kelor dan analisis kimia tepung daun kelor, 
yaitu analisis proksimat, zat besi dan kalsium, serta penentuan taraf formulasi tepung daun kelor pada pembuatan crackers.

\section{Penelitian Utama}

Penelitian utama pada penelitian ini adalah pembuatan crackers tersubstitusi tepung daun kelor dengan formulasi yang telah ditentukan. Kemudian dilakukan pengujian terhadap sifat sensori 3 formula crackers tepung daun kelor. Dari 3 formula crackers yang mendapat penilaian tertinggi dari panelis kemudian diuji kandungan proksimatnya (kadar air, lemak, abu, protein, dan karbohidrat), zat besi, dan kalsium. Formulasi crackers tepung daun kelor dapat dilihat pada Tabel 1.

\section{Rancangan Percobaan}

Rancangan percobaan pada penelitian ini yaitu rancangan acak lengkap 1 faktor dengan 2 kali pengulangan. Unit percobaan yang diamati pada penelitian ini adalah crackers dengan substitusi tepung daun kelor dengan 1 variabel independen yaitu dengan faktor perlakuan adalah konsentrasi substitusi tepung daun kelor yang terdiri atas 3 taraf yaitu 10:90, 15:85, dan 20:80 per berat tepung terigu. Data yang diperoleh dianalisis secara statistik dengan Kruskall Wallis dan dilanjutkan dengan uji Mann Whitney dengan tingkat signifikansi 95\%.

Tabel 1.

Formulasi crackers

\begin{tabular}{lrrrr}
\hline Bahan Makanan & $\mathrm{F} 0$ & $\mathrm{~F} 1$ & $\mathrm{~F} 2$ & $\mathrm{~F} 3$ \\
& $(0: 100)$ & $(10: 90)$ & $(15: 85)$ & $(20: 80)$ \\
\hline Tepung terigu (g) & 100 & 90 & 85 & 80 \\
Tepung daun kelor (g) & 0 & 10 & 15 & 20 \\
Minyak nabati (g) & 24 & 24 & 24 & 24 \\
Garam (g) & 4 & 4 & 4 & 4 \\
Baking powder (g) & 4 & 4 & 4 & 4 \\
Ragi (g) & 4 & 4 & 4 & 4 \\
Susu bubuk (g) & 12 & 12 & 12 & 12 \\
Gula halus (g) & 32 & 32 & 32 & 32 \\
Keju (g) & 32 & 32 & 32 & 32 \\
Tepung maizena (g) & 4 & 4 & 4 & 4 \\
Air (ml) & 28 & 28 & 28 & 28 \\
\hline Total Adonan (g) & \multicolumn{5}{c}{248 gram } \\
\hline
\end{tabular}


HASIL

Penelitian Pendahuluan Analisis Fisik Tepung Daun Kelor

Proses pembuatan tepung daun kelor terdiri atas lima tahap di antaranya pencucian, pengeringan dalam suhu ruang, pengeringan dalam oven, penggilingan, dan pengayakan. Pohon kelor yang berada di daerah Tiga Raksa, Tangerang memiliki batang yang sangat tinggi dan berwarna kelabu dengan daun berbentuk bulat telur dengan ukuran kecil-kecil bersusun majemuk dalam satu tangkai. Setelah daun kelor kering, daun kemudian dibawa menuju tempat pembuatan tepung. Proses pembuatan tepung selanjutnya dilakukan di Balai Pasca Panen Bogor.

Analisis sifat fisik tepung daun kelor yang dilakukan pada penelitian ini yaitu analisis rendemen tepung daun kelor. Rendemen merupakan persentase perbandingan berat akhir produk yang dihasilkan terhadap berat awal. Dari $4475 \mathrm{~g}$ daun kelor, dihasilkan tepung daun kelor sebanyak 890 g. Berat yang berkurang dengan hasil rendemen 19,8\% disebabkan adanya penurunan kadar air.

\section{Analisis Sifat Kimia Tepung Daun Kelor}

Analisis sifat kimia tepung daun kelor dilakukan di Balai Besar
Industri Agro, Bogor. Data hasil analisis sifat kimia tepung daun kelor dapat dilihat pada Tabel 2.

Tabel 2.

Sifat kimia tepung daun kelor (100 g)

\begin{tabular}{lr}
\hline Zat Gizi & Nilai \\
\hline Kadar Air (\%) & 5,17 \\
Kadar Abu (\%) & 9,52 \\
Kadar Protein (\%) & 29,45 \\
Kadar Lemak (\%) & 7,96 \\
Kadar Karbohidrat (\%) & 47,90 \\
Kadar Fe (mg/100 g) & 19,40 \\
Kadar Ca (mg/100 g) & 3018 \\
\hline
\end{tabular}

\section{Penelitian Utama}

Pada penelitian utama dilakukan pembuatan crackers tersubstitusi tepung daun kelor dengan formulasi yang telah ditentukan. Proses pembuatan crackers meliputi beberapa tahap yaitu persiapan bahan yang akan digunakan, pencampuran dan pengadukan bahan, pembuatan adonan, proses fermentasi, pembuatan lembaran adonan, pencetakan adonan, dan pemanggangan crackers.

\section{Sifat Organoleptik Crackers Tepung Daun Kelor}

Parameter yang diuji pada uji hedonik dan mutu hedonik dalam penelitian ini meliputi warna, tekstur, rasa, dan aroma. Nilai rata-rata masing-masing parameter ditunjukkan pada Gambar 1 dan Gambar 2. 


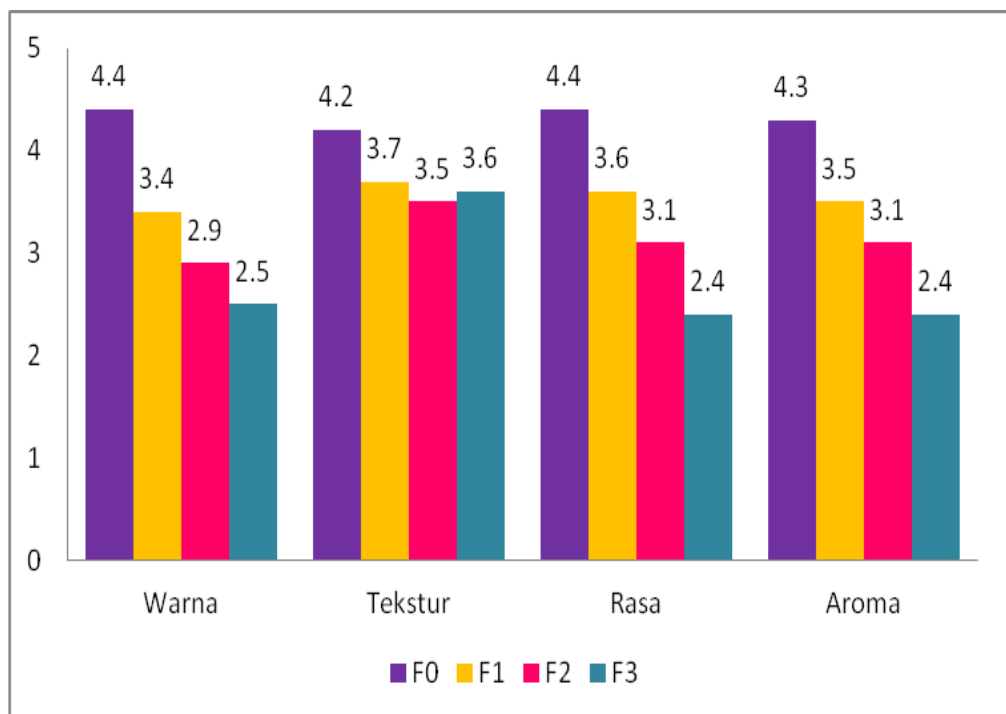

Gambar 1.

Rata-rata penilaian kesukaan crackers tepung daun kelor Keterangan: 1= sangat tidak suka, 2= tidak suka, 3= biasa, $4=$ suka, $5=$ sangat suka

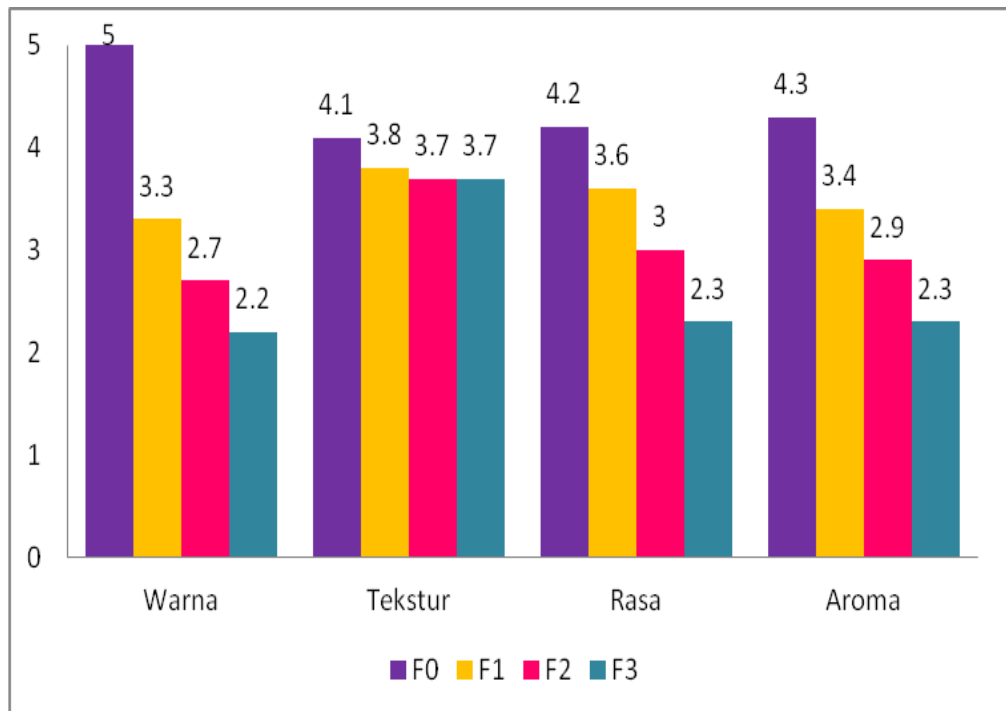

Gambar 2.

Rata-rata penilaian mutu crackers tepung daun kelor Keterangan: warna $1=$ cokelat, sampai $5=$ hijau muda kecoklatan; tekstur $1=$ sangat tidak renyah, sampai $5=$ sangat renyah; rasa $1=$ sangat pahit, sampai $5=$ sangat tidak pahit; aroma $1=$ sangat langu, sampai $5=$ sangat tidak langu. 
Warna

Warna merupakan salah satu atribut organoleptik yang penting dalam menentukan mutu bahan makanan di antara faktor lainnya seperti cita rasa, tekstur, dan aroma. Tetapi sebelum faktor-faktor lain dipertimbangkan secara visual, faktor warna tampil lebih dahulu sehingga sangat menentukan penerimaan oleh panelis (Winarno, 1997).

Berdasarkan hasil penlaian mutu hedonik, skor tertinggi pada atribut warna crackers diberikan oleh panelis pada crackers F1 $(3,3)$ yaitu hijau kecoklatan hingga hijau muda kecoklatan. Pada penilaian tingkat kesukaan (hedonik), skor tertinggi pada atribut warna crackers diberikan oleh panelis pada crackers F1 $(3,4)$ yaitu biasa hingga suka. Hasil uji Kruskall Wallis pada penilaian substitusi tepung daun kelor memiliki pengaruh nyata $(p<0,05)$ terhadap mutu warna crackers. Hasil penilaian kesukaan menunjukkan bahwa warna crackers F1 lebih disukai panelis dibandingkan dengan warna crackers F2 dan F3.

\section{Tekstur}

Berdasarkan hasil penilaian mutu hedonik, skor tertinggi pada atribut mutu tekstur crackers diberikan oleh panelis pada crackers F1 $(3,8)$ yaitu biasa hingga renyah. Pada penilaian tingkat kesukaan (hedonik), skor tertinggi pada atribut tekstur crackers diberikan oleh panelis pada crackers F1 $(3,7)$ yaitu biasa hingga suka.

Hasil uji Kruskall Wallis pada penilaian mutu hedonik menunjukkan bahwa substitusi tepung daun kelor tidak memiliki pengaruh yang nyata $(p>0,05)$ terhadap mutu tekstur crackers. Hasil uji Kruskall Wallis pada penilaian tingkat kesukaan (hedonik) menunjukkan bahwa substitusi tepung daun kelor tidak memiliki pengaruh yang nyata $(p<0,05)$ pada kesukaan panelis terhadap tekstur crackers.

\section{Rasa}

Rasa merupakan faktor penentu daya terima konsumen terhadap produk pangan. Rasa suatu produk pangan dapat dipengaruhi oleh beberapa faktor yaitu senyawa kimia, temperatur, konsistensi, dan interaksi dengan komponen rasa yang lain serta jenis dan lama pemasakan (Dewi, 2011).

Berdasarkan hasil penilaian mutu hedonik, skor tertinggi pada atribut mutu rasa crackers diberikan oleh panelis pada crackers F1 $(3,6)$ yaitu biasa hingga tidak pahit. Pada penilaian tingkat kesukaan (hedonik), skor tertinggi pada atribut rasa crackers diberikan oleh panelis pada crackers F1 $(3,6)$ yaitu biasa hingga suka.

Hasil uji Kruskall Wallis pada penilaian mutu hedonik menunjukkan bahwa substitusi tepung daun kelor memiliki pengaruh nyata $(p<0,05)$ terhadap mutu rasa crackers. Hasil uji Kruskall Wallis pada penilaian tingkat kesukaan menunjukkan bahwa 
substitusi tepung daun kelor memiliki pengaruh yang nyata $(p<0,05)$ pada kesukaan panelis terhadap rasa crackers. Hasil penilaian kesukaan panelis menunjukkan bahwa rasa crackers F1 lebih disukai panelis dibandingkan F2 dan F3.

\section{Aroma}

Bau atau aroma merupakan sifat sensori yang paling sulit untuk diklasifikasikan karena ragamnya yang begitu besar. Atribut aroma dianggap sangat penting oleh industri pangan karena dapat dengan cepat memberikan hasil mengenai kesukaan konsumen terhadap produk.

Berdasarkan hasil penilaian mutu hedonik, skor tertinggi pada atribut mutu aroma crackers diberikan oleh panelis pada crackers F1 $(3,4)$ yaitu biasa hingga tidak langu. Pada penilaian tingkat kesukaan (hedonik), skor tertinggi pada atribut aroma crackers diberikan oleh panelis pada crackers F1 $(3,5)$ yaitu biasa hingga suka.

Hasil uji Kruskall Wallis pada penilaian mutu hedonik menunjukkan bahwa substitusi tepung daun kelor memiliki pengaruh yang nyata $(p<0,05)$ terhadap mutu aroma crackers. Hasil uji Kruskall Wallis pada penilaian tingkat kesukaan (hedonik) menunjukkan bahwa substitusi tepung daun kelor memiliki pengaruh yang nyata $(p<0,05)$ pada kesukaan panelis terhadap aroma crackers.

\section{Penentuan Formula Crackers Terpilih}

Produk crackers terpilih ditentukan berdasarkan Metode Perbandingan Eksponensial (MPE) dengan cara pembobotan yang berdasarkan pada hasil analisis uji hedonik. Untuk menentukan perlakuan terbaik, setiap parameter uji hedonik diberikan skala 1-5 berdasarkan nilai kepentingannya. Semakin penting parameter, maka nilai yang diberikan semakin besar (Setyaningsih, et al., 2010). Nilai kepentingan atau pembobotan setiap parameter ditentukan secara subjektif atas berbagai pertimbangan. Penentuan formula terpilih dengan cara menjumlahkan skor rata-rata penilaian warna, tekstur, rasa dan aroma dari setiap formula. Kemudian skor rata-rata penilaian warna, tekstur, rasa dan aroma setiap formula dikalikan dengan bobot setiap parameter kesukaan. Nilai total kemudian diurutkan hingga diperoleh perlakuan terbaik. Rata-rata penilaian panelis terhadap uji hedonik crackers terdapat pada Tabel 3.

Tabel 3.

Skor penilaian setiap formulasi

\begin{tabular}{lrrrr}
\hline Penilaian & F0 & F1 & F2 & F3 \\
\hline Warna & 17,6 & 13,6 & 11,6 & 10,0 \\
Tekstur & 4,2 & 3,7 & 3,5 & 3,6 \\
Rasa & 13,2 & 7,2 & 6,2 & 4,8 \\
Aroma & 4,2 & 10,5 & 9,3 & 7,2 \\
\hline Total & $\mathbf{4 3 , 5}$ & $\mathbf{3 5 , 0}$ & $\mathbf{3 0 , 6}$ & $\mathbf{2 5 , 6}$ \\
\hline
\end{tabular}


Berdasarkan Tabel 3 dapat disimpulkan bahwa crackers terpilih dengan nilai tertinggi pada penilaian kesukaan terhadap atribut warna, tekstur, rasa, dan aroma yaitu crackers dengan substitusi tepung daun kelor sebanyak 10\% atau F1 dengan nilai 35 . Formula yang memiliki nilai tertinggi yang menjadi formula terpilih dan untuk selanjutnya dilakukan analisis kimia.

\section{Analisis Kimia Crackers Tepung Daun Kelor}

Analisis sifat kimia crackers dilakukan di Balai Besar Industri Agro, Bogor. Sifat kimia crackers terpilih dibandingkan dengan crackers kontrol untuk mengetahui pengaruh substitusi tepung daun kelor terhadap sifat kimia crackers dan SNI biskuit. Sifat kimia yang dianalisis meliputi kadar air, abu, protein, lemak, karbohidrat, energi, kalsium, dan zat besi. Hasil analisis sifat kimia crackers kontrol dan crackers terpilih disajikan pada Tabel 4.

Tabel 4.

Sifat kimia crackers terpilih (100 g)

\begin{tabular}{lrc}
\hline Parameter & $\begin{array}{c}\text { Crackers } \\
\text { Terpilih }\end{array}$ & $\begin{array}{c}\text { SNI 01- } \\
\text { 2973-2011 }\end{array}$ \\
\hline Air (\%) & 2,55 & Maks 5 \\
Abu (\%) & 4,56 & Maks 1,2 \\
Protein (\%) & 8,90 & Min 5 \\
Lemak (\%) & 16,9 & Min 9,5 \\
KH (\%) & 67,1 & Min 70 \\
Energi (kkal) & 456,10 & Min 400 \\
\hline
\end{tabular}

Seluruh parameter, kecuali abu dan karbohidrat, memenuhi persyaratan mutu crackers menurut
SNI. Kadar abu menunjukkan kadar mineral dalam pangan. Crackers daun kelor diformulasi sebagai pangan sumber kalsium, karena itu, kadar abu pangan ini cukup tinggi.

\section{DISKUSI}

Berdasarkan hasil uji hedonik terhadap atribut warna, tekstur, rasa, dan aroma dari ketiga formula crackers diketahui 1 memiliki skor kesukaan tertinggi dengan substitusi 10\% tepung daun kelor. Hasil tersebut menunjukkan bahwa konsumen lebih menyukai substitusi tepung daun kelor yang lebih sedikit. Hal ini dapat dimengerti karena semakin banyak substitusi tepung daun kelor pada pembuatan crackers, akan memengaruhi warna, tekstur, rasa, dan aroma pada crackers serta penerimaan konsumen terhadap crackers secara keseluruhan.

Tepung daun kelor yang ditambahkan akan memengaruhi warna crackers yang dihasilkan, Substitusi tepung daun kelor menyebabkan warna crackers menjadi hijau disebabkan adanya klorofil dalam tepung daun kelor. Pemanggangan dapat mengakibatkan klorofil menjadi tidak stabil dan protein terdenaturasi sehingga protein melepaskan atom hidrogen yang berasal dari gugus $\mathrm{RCH}-\mathrm{COOH}$ yang membuat sifat protein menjadi asam. Protein yang terdenaturasi dan ikatan klorofil yang tidak stabil mengakibatkan protein yang bersifat asam menyumbangkan atom hidrogen pada klorofil yang menyebabkan 
logam Mg pada klorofil menjadi terlepas sehingga terbentuk feofitin yang ditandai dengan berubahnya warna klorofil menjadi agak lebih kecoklatan (Arfandi, 2013).

Substitusi tepung daun kelor juga memengaruhi atribut aroma dan rasa. Rasa pahit pada tepung daun kelor disebabkan karena daun kelor mengandung senyawa tanin dan saponin. Menurut Ismarani (2012), tanin adalah senyawa astringent yang memiliki rasa pahit dari gugus polifenolnya sehingga dapat menyebabkan rasa kering dan sepat di dalam mulut setelah dikonsumsi. Aroma langu pada crackers disebabkan oleh senyawa saponin pada daun kelor. Saponin merupakan senyawa steroid/glukosida triterpenoid yang terikat pada karbohidrat. Senyawa tanin dan saponin dapat diminimalisasi dengan melakukan blansir.

Perlakuan blansir dapat menginaktifkan enzim-enzim oksidatif yang dapat mengakibatkan perubahan warna, aroma citarasa, dan tekstur. Kekurangan pada nilai rasa juga dapat diantisipasi dengan menambahkan bahan-bahan tertentu seperti keju,susu, cokelat, dan lain-lain yang dapat menutupi rasa pahit dan aroma langu pada crackers. Pada penelitian ini, crackers yang dihasilkan memiliki tekstur agak keras akibat adanya penambahan tepung daun kelor, serta kurang memiliki rongga udara di dalam crackers karena waktu fermentasi yang kurang. Kekurangan nilai tekstur ini dapat diatasi dengan menambahkan bahan bahan tertentu yang dapat membantu merenyahkan tekstur crackers seperti tepung maizena serta waktu fermentasi yang sesuai.

Crackers tepung daun kelor terpilih memiliki kandungan air $2,55 \%$, abu $4,56 \%$, protein $8,90 \%$, lemak 16,9\%, karbohidrat $67,1 \%$, energi $456,1 \mathrm{kkal}$, zat besi $3,05 \mathrm{mg} / 100$ g dan kalsium $324 \mathrm{mg} / 100$ g. Crackers tepung daun kelor terbaik dengan takaran saji $24 \mathrm{~g}$ memiliki kandungan energi $110 \mathrm{kkal}$, lemak $4 \mathrm{~g}$, protein $2 \mathrm{~g}$, karbohidrat $16 \mathrm{~g}$, zat besi $1 \mathrm{mg}$, dan kalsium $78 \mathrm{mg}$ per takaran saji.

Dengan mengonsumsi 12-13 keping crackers untuk dua kali selingan dapat memenuhi kebutuhan energi sebesar 20-22\%, kebutuhan karbohidrat 22-24\%, kebutuhan protein $13-14 \%$, kebutuhan lemak 23$25 \%$, kebutuhan zat besi sebesar 11$12 \%$ dan kebutuhan kalsium 26-28\% dalam sehari pada remaja putri usia (13-18) tahun.

Kandungan kalsium pada crackers sebanyak $324 \mathrm{mg} / 100 \mathrm{~g}$ sehingga dapat diklaim sebagai sumber kalsium karena telah memenuhi syarat klaim sebagai sumber mineral yaitu 15\% ALG atau $165 \mathrm{mg} / 100 \mathrm{~g}$. Kandungan zat besi pada crackers tepung daun kelor yaitu 3,05 mg/ $100 \mathrm{~g}$ tidak dapat diklaim sebagai sumber zat besi karena tidak memenuhi syarat klaim gizi yaitu $15 \%$ ALG atau 3,3 mg/100 g. 
Kadar kalsium crackers kontrol dan terpilih secara berturut-turut adalah $188 \mathrm{mg}$ dan $324 \mathrm{mg} / 100 \mathrm{~g}$. Hasil analisis kadar kalsium pada produk crackers kontrol dan crackers terpilih menunjukkan bahwa crackers terpilih memiliki kandungan kalsium yang lebih tinggi dibandingkan dengan crackers kontrol. Meningkatnya kandungan kalsium pada crackers terpilih disebabkan adanya perlakuan substitusi tepung daun kelor pada pembuatan crackers. Berdasarkan perhitungan biaya pembuatan crackers tepung daun kelor, diketahui bahwa harga jual crackers per kemasan yaitu Rp8.300,00. Bila dibandingkan dengan harga crackers komersial, harga crackers tepung daun kelor tidak jauh berbeda dengan harga crackers komersial serta memiliki kelebihan yaitu klaim sebagai makanan sumber kalsium.

\section{SIMPULAN}

Penambahan tepung daun kelor memengaruhi atribut warna, tekstur, rasa, dan aroma crackers. Crackers daun kelor terpilih dapat diklaim sebagai makanan sumber kalsium.

\section{DAFTAR RUJUKAN}

Adriani, M., dan Wirjatmadi, B. (2012). Peranan Gizi dalam Siklus Kehidupan. Jakarta: Kencana.

Almatsier, S. (2010). Prinsip Dasar Ilmu Gizi. Jakarta: Gramedia Pustaka Utama.

Arfandi, A. (2013). Proses pembentukan feofitin daun suji sebagai bahan aktif photosensitizer akibat pemberian variasi suhu. Pillar of Physics, 1: 68-76.

Balai Penelitian dan Pengembangan Kesehatan [Balitbangkes] (2013). Riset Kesehatan Dasar.

Beto, JA. (2015). The role of calcium in human aging. Clin Nutr Res, 4(1): 1-8.

Bey, H. (2010). All Things Moringa. http:/ / allthingsmoringa.com.

Denich AU. dan Ifdil. (2015). Konsep body image remaja putri. Jurnal Konseling dan Pendidikan, 3(2): 5561.

Dewi, FK. (2016). Pembuatan cookies dengan penambahan tepung daun kelor (Moringa oleifera) pada berbagai suhu pemanggangan. Skripsi. Bandung. Universitas Pasundan.

Fikawati, S., Syafiq, A., dan Puspasari, P. (2005). Faktor yang berhubungan dengan asupan kalsium pada remaja di Kota Bandung. Universa Medicina, 24(1): p-pp.

Friska, T. (2002). Penambahan sayur bayam (Amaranthus tricolor $\mathrm{L}$ ), sawi (Brassica juncea L), dan wortel (Daucus carota L) pada pembuatan crackers tinggi serat makanan. Skripsi, Bogor. FAPERTA-IPB.

Ismarani. (2012). Potensi senyawa tanin dalam menunjang produksi ramah lingkungan. CEFARS, 3(2): 46-55.

Kementrian Perindustrian. (2015). Pemberlakuan Standar Nasional Indonesia Biskuit Secara Wajib. Peraturan Menteri Perindustrian Republik Indonesia Nomor :60/MIND/PER/7/2015. 
Manley, D. (2000). Technology of Biscuits, Crackers and Cookies. England: Woodhead Publishing Limited and CRC Press CLC.

Osuagwu, O., Ega, RIA., Okoh, T., dan Oyerinde, AA. (2014). Comparative studies of physicochemical properties and mineral elements of Moringa oleifera lam. leaves in the Guinea Savannah of Nigeria. International Journal of Agriculture and Bioscience, 3(6): 266-270.

Rahmawati, RF. 2012. Pengetahuan gizi, sikap, perilaku makan dan asupan kalsium pada siswi SMA. Skripsi. Semarang. Universitas Diponegoro.

Scholl, TO. dan Hedigier, ML. (1994). Anemia and iron deficiency anemia: Compilation of data on pregnancy outcome. American journal of clinical nutrition, 59:49255015.

Setyaningsih, D., Apriyantono, A., dan Puspita M. (2010). Analisis Sensori untuk Industri Pangan dan Agro. Bogor: IPB Press.

Sondari, H. (2013). Hubungan body image dengan perilaku diet konsumsi pangan dan status gizi pada remaja putri di perkotaan dan di pedesaan. Skripsi. Bogor. Institut Pertanian Bogor.

Winarno. (1997). Kimia Pangan dan Gizi. Jakarta: Gramedia Pustaka Utama. 